\title{
Management of Technology Transfer in the Traditional Tempeh and Tofu Industries
}

\author{
Ign. Suharto ${ }^{1)}$, YIP Arry Miryanti' ${ }^{1)}$, Lita Wijaya ${ }^{1)}$ \\ 1) Department of Chemical Engineering, Faculty of Industrial Technology, Parahyangan Catholic University, Bandung \\ 40141, Indonesia \\ *Corresponding author: ign.suharto@gmail.com
}

A R T I C L I N F O
Article history:
Received date : 5 October 2018
Revised date : 11 December 2018
Accepted date : 26 December 2018
Available online at :
http://inajac.lipi.go.id
$\begin{aligned} & \text { Keywords: } \\ & \text { Rhizopus sp inoculum, soybean, } \\ & \text { tempeh, } \\ & \text { technology transfer }\end{aligned}$

\section{Abstract}

The objective of this research is to study the technology management in the context of tempeh processing and equipment based on stainless steels 304 food grade, to study management of technology transfer of the changes a filter cotton cloth bag with a manual rotary filter in the traditional tofu industry and to run an education skill training program on process and equipment in the tempeh production. The benefit of this research is to create a new business of tempeh for all people and to give policy factor in the improvement of a manual cotton cloth bag filter in the tofu industry. The method used is an operation management of production planning of preparation of Rhizopus sp inoculum, preparation of soybean as a raw material, process and equipment of a wet peeling method, a fluidized bed reactor, a sterilization tank and an artificial incubator for tempeh incubation and to run a vertical technology transfer of a manual rotary filter based on techno metric approaches. Education skill training program of 60 people in rural areas was done for tempeh production. The research results can be shown that the utilization of Rhizopus oligoporus and Rhizopus oryzae inoculum for tempeh production can be accepted by the 60 panelists and a local market needs. The improvement and utilization of tempeh processing and equipment based on material of construction of stainless steels 304 and aluminum illustrate that white mold can grow well at the fermentation time of 16 hours and put it at the open air for 8-10 hours to obtain fresh pure tempeh. Fermentation time of 16 hours for the white mold growth is faster than fermentation time of the traditional tempeh industry. Pure tempeh can be used for the preparation of first generation for a meal, second generation of tempeh flour and the third generation of pure tempeh for functional foods. Education skill training for creating competency and abilities was attended for 60 participants and some of them can create new business of diversification of tempeh production in rural areas. Management of transfer technology of a manual rotary filter in the separation of soybean slurry can act as a basic policy for the traditional tofu industry to provide a big rotary filter according to the desired capacity. Time operation of a manual rotary filter of 25 minutes with an efficiency of $66.36 \%$ is better than a manual cotton cloth bag filter of 36 minutes with an efficiency of $62.62 \%$, respectively.

(C) 2018 Indonesian Journal of Applied Chemistry. This is an open access article under the CC BY-NC-SA license (https://creativecommons.org/licenses/by-nc-sa/4.0/).

\section{INTRODUCTION}

Management of innovation is concerned with the creation of new ideas whereas management of technology focuses on the application of existing innovation [1] and technology transfer is an important follow on from research [1][2].

Management of technology transfer in the traditional tempeh and tofu industries on process and equipment is to contribute the changes of soybean process and equipment in the framework to solve one of the malnutrition problems regarding deficiency of calorie-protein, vitamin A, iron, and iodine [3].

Malnutrition problems due to the effect of food habits, a lack of knowledge, a lack of education skill training and the high cost of protein foods [2]. 
Protein foods consist of plant protein and animal protein, respectively. Animal protein is more expensive than plant protein. One of the existing sources of plant protein is soybean because this soybean contains $2,634 \mathrm{mg}$ lysine per $100 \mathrm{~g}$ of dried soybean and the lowest of methionine of $80 \mathrm{mg}$ per $100 \mathrm{~g}$ soybean [4], in comparison corn contain the highest of methionine and the lowest of lysine. Those soybean and corn can be obtained in rural areas followed by an appropriate price and source of essential amino acid. This essential amino acid of tempeh can act to solve protein-calorie malnutrition problems.

\section{Furthermore, FDA authorized.}

\section{"Soy Protein Health Claim"}

On October 26, 1990, that 25 gram of soy protein a day may reduce the risk of heart disease [5] and tempeh has anti-carcinogenic, antiosteoporotic activities, antidiarrheal, hypolipidemic effect [7].

Traditional tempeh industry is used to indicate that the traditional technology was known a long time ago [6] and tempeh originated historically hundreds of years ago before the $16^{\text {th }}$ Century from Central and East Java and the historical documents Serat Centini [6] [7].

Tempeh, a traditional fermented soybean food of Indonesia, has been taken up a teaching resource in an agricultural processing-oriented high school of Tokyo, Japan [8].

\subsection{Traditional tofu production}

Consumer accepts tofu because tofu is healthy food of highly nutritive value. The high market needs of tofu had a beneficial effect on the production of tofu. The production of tofu is produced by the traditional method, and it is difficult to create a high quality of long life tofu.

In the preparation of tofu is needed several coagulants such as $\mathrm{CaSO}_{4} \cdot 2 \mathrm{H}_{2} \mathrm{O}, \mathrm{MgCl}_{2} \cdot 6 \mathrm{H}_{2} \mathrm{O}$, $\mathrm{CaCL}_{2}, \mathrm{MgSO}_{4} .7 \mathrm{H}_{2} \mathrm{O}$, and Glucono-delta-lactone $\left(\mathrm{C}_{6} \mathrm{H}_{10} \mathrm{O}_{6}\right)$ [9], respectively.

Good tofu can be done by the heating soymilk at $70^{\circ} \mathrm{C}[9][10]$ and coagulant concentration of $2-3 \%$ weight [10] and those coagulants provide specific properties for tofu [9].

\subsection{Problem statement}

There are several problems of nutritional status in Indonesia, namely Protein deficiency can influence the brain growth for children.
Tempeh as "meat substitute" popular produced and consumed by the people in Indonesia [7].

There are several methods in tempeh inoculum preparation namely the preparation of "Usar" [11] and powdered form inoculum [11] and commercial tempeh inoculum.

The problem of an appropriate method and implementation of Rhizopus sp inoculum preparation for vulnerable group people can be done by vertical technology transfer regarding education skill training and the utilization of process and equipment based on stainless steels.

There is no national standard in the tempeh production that is needed to run education skill training on process and equipment of tempeh production for vulnerable group people.

There is popular tofu in Indonesia. One of the existing problems in the traditional tofu production is filtration of soybean slurry using a filter cotton cloth bag in order to obtain soy milk.

The changes of a manual filter of cotton cloth bag with a manual rotary filter that is needed to transfer of a manual rotary filter to the traditional tofu industry.

\subsection{The objective}

The objective is to study the operation management of tempeh inoculum of Rhizopus sp, the operation management of the improvement of tempeh fermentation technology and equipment based on stainless steel 304 food grade, to study a vertical technology transfer of the changes a filter cotton cloth bag with a manual rotary filter in the traditional tofu industry and finally to run an education skill training program on process and equipment in the tempeh production.

\subsection{The benefit}

The benefit of this research is to create a new business of tempeh and tofu processing for all people and to increase the productivity and efficiency in the traditional tempeh production and finally, a manual rotary filter as a basic policy for the traditional tofu industry to provide a big rotary filter according to the desired capacity.

\section{MATERIAL AND METHOD}

Management of technology transfer in the traditional tempeh and tofu industries based on the principles and practices of management of 
Plan-Do-Action-Control or P-D-A-C and techno metric approaches [11][12][13].

\subsection{Management of operation on tempeh inoculum and tempeh production}

The operation management activity on tempeh inoculum production based on the input and process and finally output of tempeh inoculum product or input-output process.

The role of tempeh inoculum production and the data to achieve of $F_{1}, F_{2}, F_{3}$ inoculum [14][15] and to explain tempeh fermentation [14] and there are several methods of tempeh fermentation [16] and transfer technology from research result to industry [1][2][14][15]

Operation management of tempeh inoculums can be described as follows;

The suspension in order to obtain an $F_{1}$ inoculum can be done by the 100 gram rice is put in the autoclave at $120^{\circ} \mathrm{C} @ 15$ minutes and steamed rice is cooled at a room temperature and after that it is inoculated by Rhizopus oligosporus and Rhizopus oryzae and finally, it is incubated at temperature of $30^{\circ} \mathrm{C} @ 3$ days. This inoculum of $\mathrm{F}_{1}$ is dried at $37^{\circ} \mathrm{C} @$ four days. This $\mathrm{F}_{1}$ inoculum is ground by a grinder and a vibrating screen completed with a wire mesh screen in order to get $F_{1}$ inoculum powder. Preparation of $F_{2}$ inoculum is derived from the $F_{1}$ inoculum with a similar procedure, and finally, $F_{3}$ inoculum is derived from $F_{2}$ inoculum.

$\mathrm{F}_{3}$ inoculum is used in the tempeh fermentation to produce a high quality of pure tempeh without soybean skin and other additives.

\subsection{Management of operation on tempeh production}

There are three sorts of operation management method tempeh fermentation, namely preparation of tempeh inoculums, sterilized dehulled soybean and incubation of perforated plastic cylinder or tray containing inoculated dehulled soybean.

The operation management is concerned with the harmonization of those three of input, process, and product [13][14][17], respectively.

The processing input in the form of cleaned soybean, tempeh inoculums, equipment, energy, skill, and motivation. The process is the fermentation technology on soybean. The output is a tempeh product. Management of operation on tempeh production can be made by soybean as the following [14];

\subsection{Management of operation on boiling stainless steels 304 tank}

The function of boiling stainless steels 304 tanks of soybean is to allow cleaned soybean absorb water for the preparation of wet peeling machine.

Cleaned soybean is boiled at $95^{\circ} \mathrm{C} @ 45$ minutes in the boiling stainless steels 304 tanks in order to facilitate a softly boiled soybean. Technical specification of a boiling tank with the thickness of $1.5 \mathrm{~mm}$, the diameter of $60 \mathrm{~cm}$ and height of $60 \mathrm{~cm}$.

\subsection{Management of operation on wet peeling machine}

Boiled soybean entered between two stainless steel roll to make size reduction of soybean into soybean meat and soybean skin. This stainless steel 304 is not a smooth one and grooved in order to increase productivity and efficiency. The capacity of wet peeling method is $33 \mathrm{~kg}$ per hour [14].

Fig. 2 illustrates that the function of wet peeling method is to make a size reduction of boiled soybean into soybean meat and soybean skin and also to remove soybean skin.

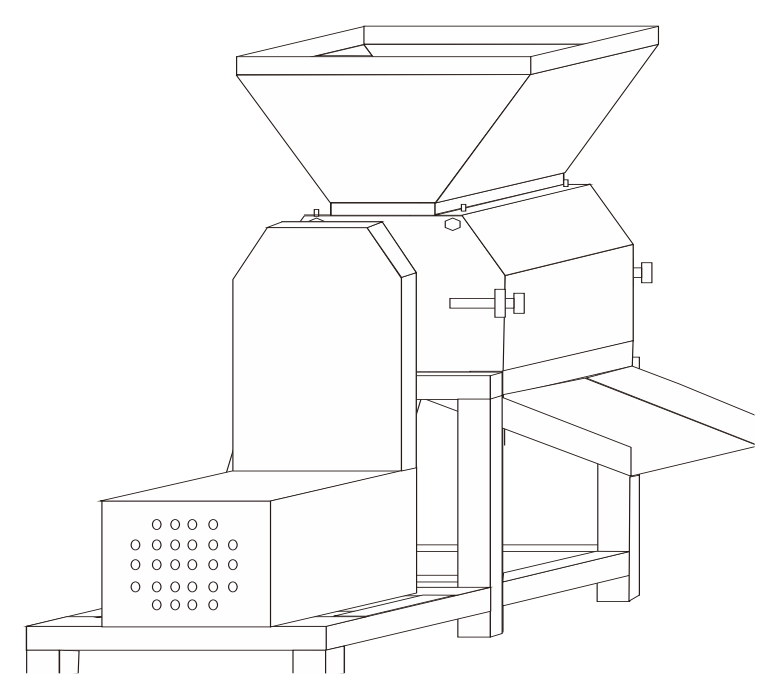

Fig.1. A prototype of a wet peeling machine [14] 


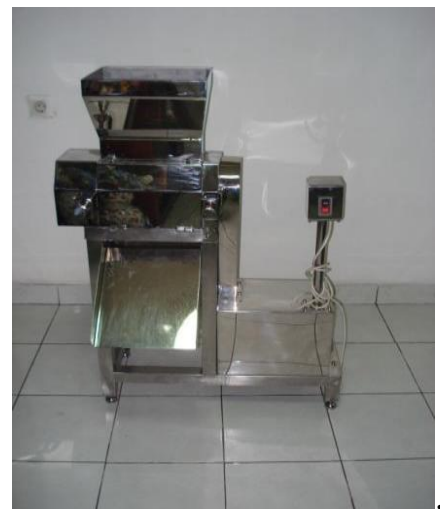

Fig.2. Construction of wet peeling machine for boiled soybean [14].

\subsection{Management of operation on fluidized bed reactor}

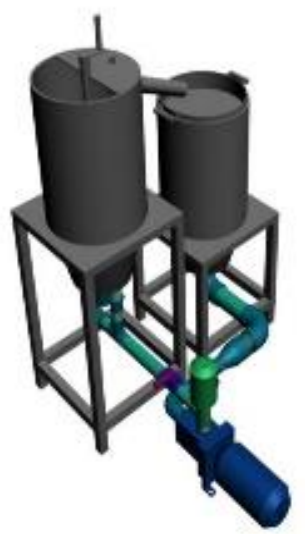

Fig.3. A prototype of fluidized bed reactor for the separation of soybean skin and soybean meat [14]

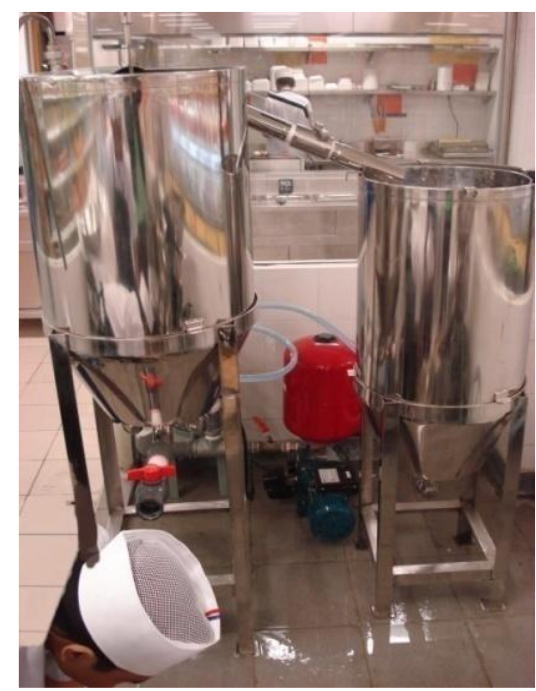

Fig.4. Construction of fluidized bed reactor for the separation of soybean skin and soybean meat [14]
Figure 4 illustrates that the function of the fluidized reactor is to separate soybean skin and soybean meat. Cleaned soybean meat can be used in the preparation of tempeh fermentation in order to obtain a high quality of pure tempeh. This fluidized bed reactor based on two-phase of water and dehulled soybean and soybean skin. The density of dehulled soybean is larger than the density of soybean skin. Soybean skin at the surface of the water in the first tank of stainless steels 304 and then wet soybean skin flowing through a stainless steels pipe of 2.54 $\mathrm{cm}$ diameter into the second stainless steels storage tank completed with a mesh screen to collect wet soybean skin.

\subsection{Management of operation on water soaking of dehulled soybean}

Stainless steel 304 tank is used to soak dehulled soybean in the ratio of water: soybean of 2: 1 for 24-36 hours to reduce $\mathrm{pH}$ values of about $4.0-4.5$

\subsection{Management of operation on sterilization of dehulled soybean}

Dehulled soybean is boiled at $95^{\circ} \mathrm{C} @ 2-3$ hours at the boiling stainless steel 304 tank containing clean water in order to obtain a soft sterilized dehulled soybean.

\subsection{Perforated stainless steel 304}

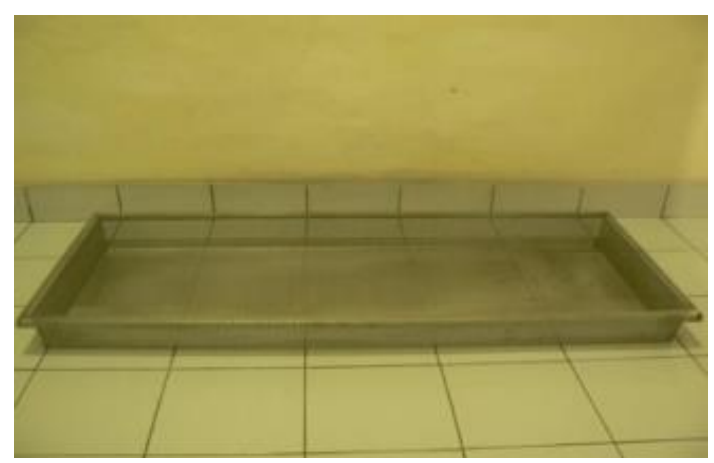

Fig.5. Construction of perforated stainless steel 304 trays [14].

Figure 5 illustrates that the function of perforated stainless steel 304 trays is to reduce the water content of sterilized dehulled soybean until of about $65 \%$. 


\section{pp. 69-78, December 2018}

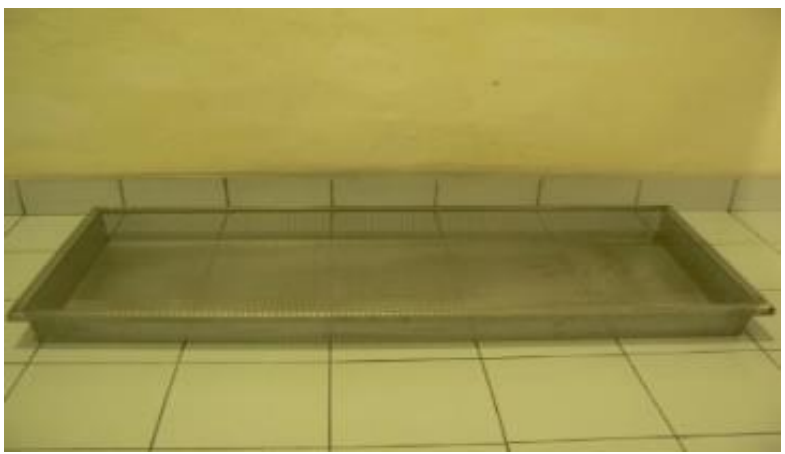

Fig.6. Construction of non-perforated stainless steel 304 trays for food grade [14]

Figure 6 illustrates that the function of non-perforated stainless steel 304 trays is to mix the sterilized dehulled soybean and tempeh inoculum. The dimensions of stainless steel 304 trays of $100 \mathrm{~cm}$ in length, and $40 \mathrm{~cm}$ in width, respectively

Figure 7 illustrates that an artificial aluminum incubator can be used in the tempeh fermentation in order to obtain pure tempeh. The incubation of sterilized dehulled soybean by tempeh inoculum at $30^{\circ} \mathrm{C} @ 16$ hours can grow well of white molds of Rhizopus oligosporus and Rhizopus oryzae

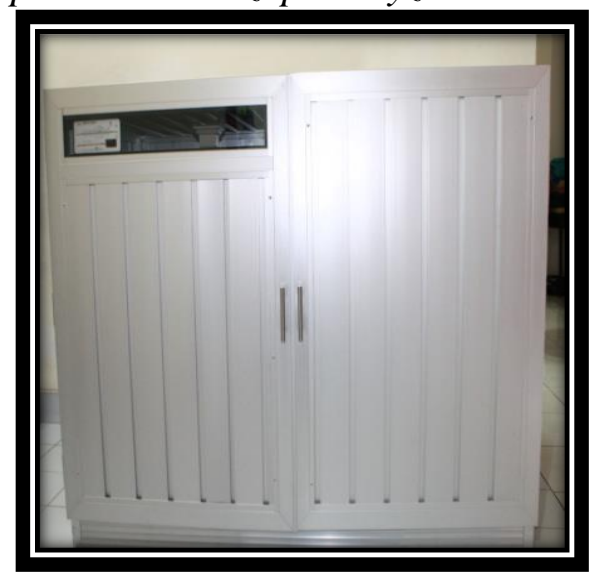

Fig.7. Construction of an artificial Aluminum incubator [14]

Figure 7 illustrates that $1 \mathrm{~kg}$ meat soybean is inoculated by 3 -gram tempeh inoculum and incubated at $30^{\circ} \mathrm{C} @ 16$ hours to produce a white mold of tempeh and then this tempeh is cooled in the open air to reduce heat inside of tempeh in order to produce pure tempeh product.

\subsection{Education skill training on a perforated plastic cylinder containing inoculated dehulled soybean}

Figure 8 illustrates that the creation of a new business, there will be needed an education skill raining of process and equipment for tempeh production.

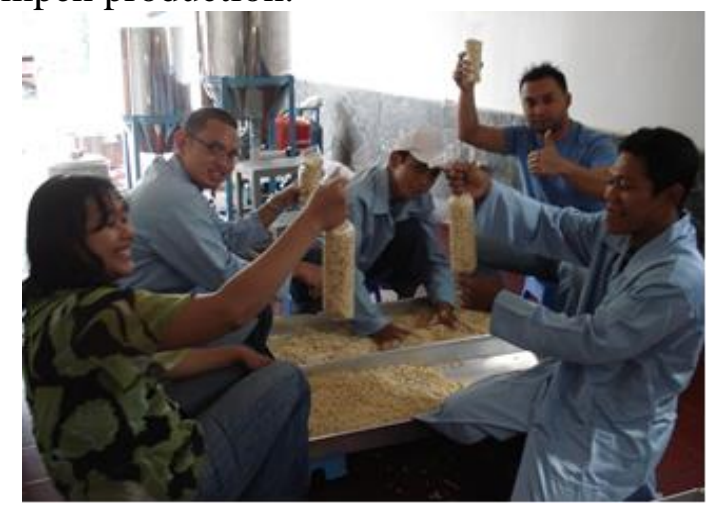

Fig.8. The education skill training people are preparing perforated plastic cylinder containing inoculated dehulled soybean [14].

\subsection{Management of operation of tofu method}

Silk tofu can be produced by the following method; ratio dehulled soybean and water of 1: 8 at the temperature of $80^{\circ} \mathrm{C}$ is ground by a hammer mill in order to produce soybean slurry.

Filtration of soybean slurry in the traditional soybean industry using a filter cotton cloth bag in order to obtain soy milk.

For silk tofu production, the soymilk was heated of $70^{\circ} \mathrm{C}$ and the addition of $0.4 \% \mathrm{w} / \mathrm{v}$ $\mathrm{CaSO}_{4}$ and $0.4 \%$ w/v Glucono-Delta Lactone in order to produce silk tofu [15].

\subsection{Management of vertical transfer of technology on a manual rotary filter}

A manual cotton cloth bag filter is replaced by a manual rotary filter based on the material of construction of stainless steel 304 in order to increase the productivity and efficiency on filtration unit of soybean slurry in the hygiene control.

A manual cotton cloth bag filter is replaced by a manual rotary filter based on the material of construction of stainless steels 304 food grade.

Vertical technology transfer in a manual rotary filter of traditional tofu industry is needed three steps, namely the first step is to give a score on each parameter of techno metric in terms of techno ware, human ware, 
info ware, and oregano ware, [12] the second step is to calculate the rating state of the Arts, namely state of the Art of techno ware, state of the Art of human ware, state of the Art of info ware, and state of the Art of oregano ware, respectively [12] and finally the third step is the calculation of each component contribution. Of techno ware, human ware, info ware, and oregano ware, respectively.

Technology Contribution Coefficient is estimated by the following equation [12]

$\mathrm{T}_{1}=\frac{1}{9}\left[\mathrm{LT}_{\mathrm{i}}+\mathrm{ST}_{\mathrm{i}}\left(\mathrm{UT}_{\mathrm{i}}-\mathrm{LT}_{\mathrm{i}}\right)\right]$ for Techno ware $\mathrm{H}_{\mathrm{j}}=\frac{1}{9}\left[\mathrm{LH}_{\mathrm{j}}+\mathrm{SH}_{\mathrm{j}}\left(\mathrm{UH}_{\mathrm{j}}-\mathrm{LH}_{\mathrm{j}}\right)\right]$ for Human ware $I_{k}=\frac{1}{9}\left[L_{k}+S_{k}\left(U_{k}-L I_{k}\right)\right] \quad$ for Info ware $\mathrm{O}_{\mathrm{L}}=\frac{1}{9}\left[\mathrm{LO}_{\mathrm{L}}+\mathrm{SO}_{\mathrm{L}}\left(\mathrm{UO}_{\mathrm{L}}-\mathrm{LO}_{\mathrm{kL}}\right)\right]$ for Organo ware

where $\mathrm{L}=$ Lower limit, $\mathrm{U}=$ Upper limit and $\mathrm{S}=$ State of the Arts.

Technology Contribution Coefficient (TCC);

$$
\mathrm{TCC}=\mathrm{T} \beta_{T}+\mathrm{I} \beta_{I}+\mathrm{H} \beta_{H}+\mathrm{O} \beta_{O}
$$

The differential equation can be given as the following

$$
\begin{gathered}
\frac{\delta T C C}{\delta T} \quad \beta_{T} \frac{\delta T}{T}+\beta_{H} \frac{\delta(H)}{H}+\beta_{I} \frac{\delta(I)}{I}+\beta_{O} \frac{\delta(O)}{o} \text { or } \\
\ln \mathrm{TCC}=T^{\beta_{T}}+H^{\beta_{H}}+I^{\beta_{I}}+O^{\beta_{O}} \text { or } \\
\mathrm{TCC}=T^{\beta_{T}} \times H^{\beta_{H}} \times I^{\beta_{I}} \times O^{\beta_{o}}
\end{gathered}
$$

The value of $\beta_{T}, \beta_{H}, \beta_{I}, \beta_{o}$ between zero to one can be calculated and finally those coefficients can be validated. The values of T, $\mathrm{H}, \mathrm{I}$, and $\mathrm{O}$ can act as the contribution of each $\mathrm{T}, \mathrm{H}, \mathrm{I}$, and $\mathrm{O}$ to the Total Technology Contribution Coefficient (TCC).

\section{RESULTS AND DISCUSSION}

\subsection{Management of operation on tempeh inoculum and tempeh product}

The purpose of the tempeh inoculum preparation of $\mathrm{F}_{3}$ inoculum can be produced by the people in rural areas so that there is needed an education skill training of rural people. There are several traditional methods of tempeh production [16], and there is no national standard of tempeh processing $n$ this research that all equipment based on the material of construction of stainless steels 304 food grade for fermentation of dehulled soybean in order to produce pure tempeh.

This method of tempeh preparation using stainless steels 304 equipment according to the sanitation and hygiene control is very different from the traditional tempeh production.

The utilization of wet peeling method of boiled soybean can act as a contribution to increasing productivity and efficiency in the tempeh production. The utilization of an artificial aluminum incubator completed with ON/OFF temperature control is to make shorter fermentation time of tempeh of about 16 hours followed by cooling fresh tempeh in the open air of about 8 hours to reduce heat inside fresh tempeh and finally to obtain a white mold of pure fresh tempeh.

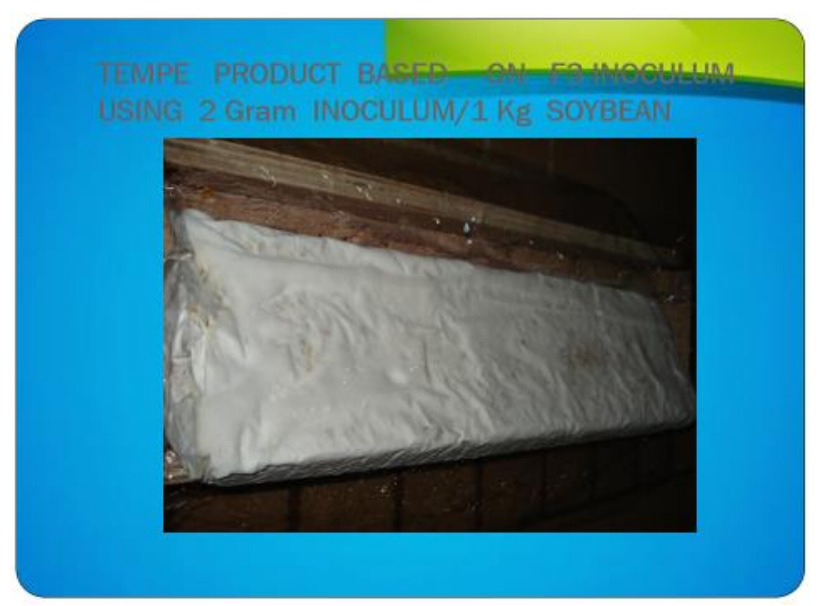

Fig.9. The high quality of pure tempeh for the production of the second and the third generation of tempeh

Figure 9 illustrates that big tempeh was produced at the stainless steels 304 trays with the dimension of $98 \mathrm{~cm}$ length, $8 \mathrm{~cm}$ height, and $40 \mathrm{~cm}$ width.

The first generation of pure tempeh can be used for the daily meal. The second generation of pure tempeh can be used for the production of tempeh flour. The third generation of pure tempeh can be used for functional foods.

Commercial tempeh product at the traditional market containing soybean skin in the tempeh product, it is not a high quality of tempeh to produce second and the third generation of tempeh. 


\subsection{Education skill training Training program as a vertical transfer technology}

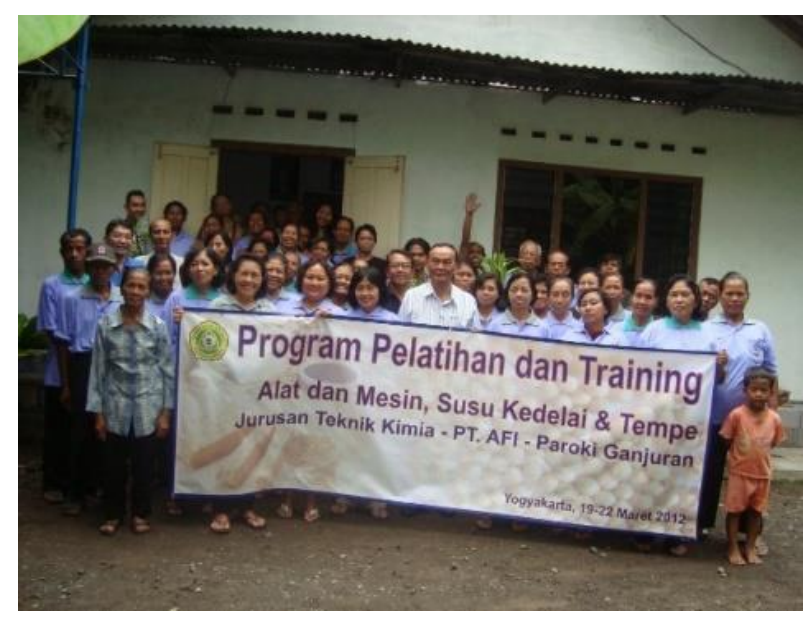

Fig.10. Education skill training requirement for personnel to create a new business of tempeh in rural areas [14]

Figure 10 illustrates that all women attended this training in order to get substantial profit and intangible profit. Intangible profit for all participants is pride in creating a new business of tempeh and motivation and strengthening of teamwork. This is a training requirement for personnel was done because of the existing market needs of tempeh product in the local market.

The objective of education skill training is to make understanding the process and equipment in the tempeh production and to develop the ability to create a new business of a high quality of pure tempeh for all people. The importance of sharing of all participants in this training is to increase technical skill, responsibility, and information in the tempeh production, existing tempeh product and present market of tempeh.

\subsection{A manual rotary filter}

There is much information in the traditional tofu industry regarding what is a manual rotary filter, how is a manual rotary filter different from a manual cotton cloth bag filter, why does the traditional tofu industry need a manual rotary filter, what is innovation, how is manual rotary filter productivity and efficiency. Therefore the techno metric approach can act as technology contribution coefficient of a manual rotary filter is very important to be done.
Techno metric consists of four parameters, namely; Techno ware $(\mathrm{T})$, Human ware $(\mathrm{H})$, Info ware (I), and Organic ware (O) [12], respectively.

A manual rotary filter is created and implemented for the traditional tofu industry to increase the productivity and efficiency. Therefore there is a vertical technology transfer.

Filtration of soybean slurry in the traditional soybean industry using a filter cotton cloth bag in order to obtain soy milk but this filtration process is not an appropriate method. Therefore there will be needed innovation of filtration using a filter cotton cloth bag into a standard rotary filter. This a manual rotary filter is better than a filter cotton cloth bag.

A manual rotary filter with an efficiency of $66.37 \%$ for 25 minutes but a manual filter cotton cloth bag filter with an efficiency of $62.62 \%$ for 36 minutes that means there is an improvement according to the productivity and efficiency and hygiene control.

Table 1. Comparison of a manual cotton cloth bag filter and a manual rotary filter

\begin{tabular}{|l|c|c|}
\hline Soymilk product & $\begin{array}{c}\text { A manual } \\
\text { rotary } \\
\text { filter }\end{array}$ & $\begin{array}{c}\text { A manual } \\
\text { filter cotton } \\
\text { cloth bag }\end{array}$ \\
\hline $\begin{array}{l}\text { The yield of } \\
\text { soymilk, \% }\end{array}$ & 66.30 & 62.63 \\
\hline $\begin{array}{l}\text { Filtration time, } \\
\text { minutes }\end{array}$ & 25 & 36 \\
\hline $\begin{array}{l}\text { Solid particle } \\
\text { content, \% }\end{array}$ & 25,75 & 28,85 \\
\hline
\end{tabular}


pp. 69-78, December 2018

Table 2. Determination of the upper and lower limit

\begin{tabular}{|l|c|c|}
\hline \multicolumn{1}{|c|}{ Component } & Upper limit & Lower limit \\
\hline Technoware & Uti & It \\
\hline Filtration & 3 & 1 \\
\hline Grinder & 4 & 2 \\
\hline Steam boiler & 4 & 2 \\
\hline Humanware & UHj & Lhj \\
\hline Criteria & 3 & 1 \\
\hline Infowars & Rik & Lik \\
\hline Process production & 3 & 1 \\
\hline Book keeping & 5 & 1 \\
\hline Organoware & UOi & 2 \\
\hline Criteria & 4 & 2 \\
\hline
\end{tabular}

Table 3. Determination of State of the Art of filtration

\begin{tabular}{|l|l|l|l|l|c|}
\hline No. & Criteria & $\begin{array}{c}\text { Criteria } \\
\text { value }\end{array}$ & $\mathbf{0}$ & $\mathbf{1 0}$ & Value \\
\hline 1. & Filtration & $\begin{array}{l}\text { Semi } \\
\text { continue }\end{array}$ & Batch & Continue & 5 \\
\hline 2. & Mechanism & Manual & Manual & Electrical & 0 \\
\hline \multicolumn{5}{|l}{ Total } & 5 \\
\hline
\end{tabular}

Calculation State of the Arts for hammer mill $\mathrm{STi}=\frac{1}{10}\left[\frac{5+0}{2}\right]=\mathbf{0 . 2 5}$

Table 4 Determination of State of the Art of Grinder

\begin{tabular}{|c|l|l|l|l|l|}
\hline No. & Criteria & $\begin{array}{l}\text { Criteria } \\
\text { Value }\end{array}$ & \multicolumn{1}{|c|}{ 0 } & \multicolumn{1}{|c|}{$\mathbf{1 0}$} & Value \\
\hline 1. & $\begin{array}{l}\text { Rotation } \\
\text { grinder }\end{array}$ & $\begin{array}{l}1600 \\
\mathrm{rpm}\end{array}$ & $800 \mathrm{rpm}$ & $\begin{array}{l}1800 \\
\mathrm{rpm}\end{array}$ & 8 \\
\hline 2. & Capacity & $\begin{array}{l}750 \\
\mathrm{~kg} / \mathrm{hour}\end{array}$ & $\begin{array}{l}50 \\
\mathrm{~kg} / \mathrm{hour}\end{array}$ & $\begin{array}{l}850 \\
\mathrm{~kg} / \mathrm{hr}\end{array}$ & 9 \\
\hline 3. & Power & $3 \mathrm{hp}$ & $1 \mathrm{Hp}$ & $50 \mathrm{hp}$ & 1 \\
\hline
\end{tabular}

Calculation State of the Arts for Grinder

$\mathrm{Ti}=\frac{1}{10}\left[\frac{8+9+1}{3}\right] \quad=\mathbf{0 . 6 0}$
Table 5 Determination of State of the Art of Steam Boiler

\begin{tabular}{|c|l|l|l|l|l|}
\hline No. & Criteria & $\begin{array}{l}\text { Criteria } \\
\text { Value }\end{array}$ & \multicolumn{1}{|c|}{$\mathbf{0}$} & $\mathbf{1 0}$ & Value \\
\hline 1. & Power & $10 \mathrm{hp}$ & $10 \mathrm{hp}$ & $30 \mathrm{hp}$ & 0 \\
\hline 2. & Capacity & $\begin{array}{l}1570 \\
\mathrm{~L}\end{array}$ & $\begin{array}{l}500 \\
\mathrm{~L}\end{array}$ & $\begin{array}{l}2000 \\
\mathrm{~L}\end{array}$ & 8 \\
\hline
\end{tabular}

Calculation State of the Arts for Steam Boiler $\mathrm{STi}=\frac{1}{10}\left[\left[\frac{8+0}{3}\right] \quad=\mathbf{0 . 4 0}\right.$

Normalized contribution

$\mathrm{Ti}=\frac{1}{9}[1+0.25(3-1)]=0.17$

$\mathrm{Ti}=\frac{1}{9}[2+0.60(4-2)]=0,36$

$\mathrm{Ti}=\frac{1}{9}[2+0.40(4-2)]=0.31$

Ti average $=\frac{(0.17+0.36+0.31)}{3}=\mathbf{0 . 2 8}$

Table 6 The calculation of for Human ware $(\mathrm{Hj})$

\begin{tabular}{|c|c|c|c|c|}
\hline Humanware & $\mathbf{U H j}$ & $\mathbf{L H j}$ & $\mathbf{S H j}$ & $\mathbf{H j}$ \\
\hline Criteria & 3 & 1 & 0,61 & \\
\hline
\end{tabular}

$\mathrm{Hj}=\frac{1}{9}[1+0.61(3-1)=\mathbf{0 . 2 5}$

Table 7 The calculation of Info ware (Ik)

\begin{tabular}{|l|c|c|c|c|}
\hline \multicolumn{1}{|c|}{ Infoware } & UIk & LIk & SIk & Ik \\
\hline $\begin{array}{l}\text { Production } \\
\text { Process }\end{array}$ & 3 & 1 & 0.62 & 0.25 \\
\hline $\begin{array}{l}\text { Book } \\
\text { keeping }\end{array}$ & 5 & 3 & 0.50 & 0.44 \\
\hline
\end{tabular}

Ik average $\frac{(0.25+0.44)}{2}=\mathbf{0 . 3 4}$

Table 8 The calculation of Organo ware (OL)

\begin{tabular}{|c|c|c|c|c|}
\hline Infoware & $\mathbf{U O}_{\mathbf{L}}$ & $\mathbf{L O}_{\mathbf{L}}$ & $\mathbf{S O}_{\mathbf{L}}$ & $\mathbf{O}_{\mathbf{L}}$ \\
\hline Criteria & 4 & 2 & 0.37 & 0.30 \\
\hline
\end{tabular}

$\mathrm{O}_{\mathrm{L}}=\frac{1}{9}[2+0.37(4-2)=\mathbf{0 . 3 0}$

Technology Contribution Cofficient or $\mathrm{TCC}=0.28^{\beta_{T}} \times 0.25^{\beta_{H}} \times 0.34^{\beta_{I}} \times 0.30^{\beta_{o}}$

Table 9 The matrix of intensity contribution

\begin{tabular}{|c|c|c|c|c|}
\hline $\mathbf{C}$ & $\mathbf{T}$ & $\mathbf{H}$ & $\mathbf{I}$ & $\mathbf{O}$ \\
\hline $\mathbf{T}$ & $\mathrm{a}_{11}$ & $\mathrm{a}_{12}$ & $\mathrm{a}_{13}$ & $\mathrm{a}_{14}$ \\
\hline $\mathbf{H}$ & $\mathrm{a}_{21}$ & $\mathrm{a}_{22}$ & $\mathrm{a}_{23}$ & $\mathrm{a}_{24}$ \\
\hline $\mathbf{I}$ & $\mathrm{a}_{31}$ & $\mathrm{a}_{32}$ & $\mathrm{a}_{33}$ & $\mathrm{a}_{34}$ \\
\hline $\mathbf{O}$ & $\mathrm{a}_{41}$ & $\mathrm{a}_{42}$ & $\mathrm{a}_{43}$ & $\mathrm{a}_{44}$ \\
\hline
\end{tabular}

The value of $a_{11}, a_{22}, \quad a_{33}, a_{44}=1$

These values of $a_{12}=2, a_{13}=4, a_{14}=5, a_{23}=4$, $a_{34}=3$ can be obtained according to the ratio of 
two values consideration. The value of 5 can be obtained according to the most important value compared with the other values and aij $=\frac{1}{a j i}$.

Illustration to calculate of $\beta_{T}, \beta_{H}, \beta_{I}, \beta_{o}$

Table 10 Matrix H, T, I, O

\begin{tabular}{|c|c|c|c|c|}
\hline $\mathbf{C}$ & $\mathbf{T}$ & $\mathbf{H}$ & $\mathbf{I}$ & $\mathbf{O}$ \\
\hline $\mathbf{T}$ & 1 & 2 & 4 & 5 \\
\hline $\mathbf{H}$ & $1 . / 2$ & 1 & 2 & 4 \\
\hline $\mathbf{I}$ & $1 / 4$ & $1 / 2$ & 1 & 3 \\
\hline $\mathbf{O}$ & $1 / 5$ & $1 / 4$ & $1 / 5$ & 1 \\
\hline Total & 1,95 & 3,75 & 7,2 & 13 \\
\hline
\end{tabular}

Table 11 Matrix to calculate of $\beta_{T}, \beta_{H}, \beta_{I}, \beta_{O}$

\begin{tabular}{|c|c|c|c|c|c|c|}
\hline $\mathbf{C}$ & $\mathbf{T}$ & $\mathbf{H}$ & $\mathbf{I}$ & $\mathbf{O}$ & Total & Average \\
\hline $\mathbf{T}$ & 0,51 & 0.53 & 0.55 & 0.38 & 1.97 & 0.49 \\
\hline $\mathbf{H}$ & 0.26 & 0.27 & 0.28 & 0.31 & 1.12 & 0.28 \\
\hline $\mathbf{I}$ & 0.13 & 0.13 & 0.14 & 0.23 & 0.63 & 0.16 \\
\hline $\mathbf{O}$ & 0.21 & 0.07 & 0.03 & 0.08 & 0.39 & 0.10 \\
\hline
\end{tabular}

Remarks: This is the example to calculate the value of $0.51 ; 0.26 ; 0.13 ; 0.21$

$\frac{1}{1.95}=0.51 ; \frac{1 / 2}{1.95}=0.26 ; \frac{1 / 4}{1.95}=0.13 ; \frac{1 / 5}{1.95}=0.21$

Table 12 Component, overall contribution, component contribution and TCC

\begin{tabular}{|c|c|c|c|}
\hline Component & $\begin{array}{c}\text { Over all } \\
\text { contribution }\end{array}$ & $\begin{array}{l}\text { Component } \\
\text { contribution }\end{array}$ & $\begin{array}{l}\text { TCC } \\
\text { value }\end{array}$ \\
\hline Techno ware & 0.28 & 0.49 & \multirow{4}{*}{0.27} \\
\hline Human ware & 0.25 & 0.28 & \\
\hline Info ware & 0.35 & 0.16 & \\
\hline Organo ware & 0.30 & 0.10 & \\
\hline $\begin{array}{l}\text { The value } 0 \\
\mathrm{x} O^{\beta_{o}}\end{array}$ & $\mathrm{TCC}=T^{\beta_{T}}$ & $\mathrm{x} H^{\beta_{H}}$ & $\times I^{\beta_{I}}$ \\
\hline
\end{tabular}

\section{CONCLUSION}

The research results can be shown that;

1. The utilization of Rhizopus oligoporus and Rhizopus oryzae inoculum for tempeh production can be accepted by the 60 panelists, and a local market need.

2. The improvement and utilization of tempeh processing and equipment based on material of construction of stainless steels 304 and aluminum can improve productivity and efficiency of tempeh production.
3. These tempeh equipment of stainless steels 304 illustrate that white mold can grow well at the fermentation time of 16 hours and put it at the open air for 8-10 hours to obtain a high quality of fresh, pure tempeh.

4. Fermentation time of 16 hours for the white mold growth is faster than fermentation time of the traditional tempeh industry of 36 hours.

5. Pure tempeh can be used for the preparation of the first generation for daily meals, second generation for tempeh flour and finally the third generation of pure tempeh for functional foods.

6. Education skill training for creating competency and abilities was attended for 60 participants and some of them can a create a new business of diversification of tempeh product in rural areas.

7. Transfer of a manual rotary filter in the separation of soybean slurry can act as a basic policy for the traditional tofu industry to provide a big rotary filter according to the desired capacity.

8. Operation management of a manual rotary filter of 25 minutes with an efficiency of $66.36 \%$ is better than a manual cotton cloth bag filter of 36 minutes with an efficiency of $62.62 \%$, respectively.

9. The Technology Contribution Coefficient for a manual rotary filter is higher than the Technology Contribution Coefficient for a manual filter cotton cloth bag in the traditional tofu industry.

\section{ACKNOWLEDGEMENT}

I would like to thanks to Pusat Penelitian KimiaLIPI Serpong who have assisted me to publish this scientific paper.

\section{REFERENCES}

[1]. Noori, H. Managing The Dynamics of New Technology, pp 100-115, Prentice Hall, Englewood, New Jersey 07632, 1990.

[2]. Soriano, MR, ASEAN Food Technology Research and Development Project 1982-1990. p.4, Kasetsart University, Bangkok, 1990. 
[3]. S. Widowati, B.A.S Santosa, Sumarno, Role of Soybean and Its Products in Food and Rural Development in Indonesia, p 591, Proceedings the Third International Soybean Processing and Utilization Conference, October 15-20, Tsukuba, Ibaraki, Japan, 2000.

[4]. Lie Goan Hong and Oey Kam Nio, Food Evaluation and Community Nutrition, National Institute for Chemistry, Bandung, 1980.

[5]. Fukusima, D., Recent Progress in Research and Technology for Processing \& Utilization of Soybean, p 11, Proceedings The Third International Soybean Processing and Utilization Conference, October 15-20, Tsukuba, Ibaraki, Japan, 2000.

[6]. Mary Astuti, Sejarah Perkembangan Tempe, p 21, Bunga Rampai Tempe Indonesia, Yayasan Tempe Indonesia, Jakarta, 1996.

[7]. Darwin Karyadi, Wijaya Lukito, Tempe as a Functional Food and Contemporary Nutrition - Health Paradigm. Its Potential Beneficial Effects in Disease Prevention and Treatment, $p$ 711, Proceedings The Third International Soybean Processing and Utilization Conference, October 15-20, Tsukuba, Ibaraki, Japan, 2000.

[8]. Yasunobu Tokuda, Tempe Developed In High School Curriculum In Japan, Tokyo Metropolitan Agricultural High School, p 351, Proceedings The Third International Soybean Processing and Utilization Conference, October 15-20, Tsukuba, Ibaraki, Japan, 2000.

[9]. Watanabe,T., Science of Tofu, Food Journal Co., Ltd. Kyoto, Japan, 1996.

[10]. Onggo, R.W., Suharto, Ign., Ramadhany, P., Pengaruh Temperatur, GDL dan CaSO4 dalam Susu Kedelai Terhadap Perolehan Tahu Sutera, Jurusan Teknik Kimia, Fakultas Teknologi Industri-Unika Parahyangan, Bandung, 2018.

[11]. Sri Hartadi, Inoculum Preparation For Tempe and Soysauce Fermentation, Report of the Second ASEAN Workshop On Solid Substrate Fermentation, 27-28 November 1980, Kuala Lumpur, Malaysia, 1980.
[12]. Djoko Pitono, Atlas Teknologi, Pusat Analisa Perkembangan IPTEK, LIPI, Jakarta, 1990.

[13]. Freeman-Bell, G., and Balkwill, J., Management In Engineering, $2^{\text {nd }} \mathrm{Ed}$. Prentice Hall, New York, 1996.

[14]. Suharto, Ign., Innovation Process Equipment of Tempe Industries without Pollution. LAP LAMBERT Academic Publishing AV Akademikerverlag GmbH \& Co.KG, Heinrich- Bocking. Str, 6-8, 66121, Saarbrucken, Germany, 2012.

[15]. Suharto,Ign.; A.Prima, K; YIP Arry Miryanti [2011] Technology Transfer to Industry of Biotechnology on Rhizopus sp Inocuum,International Conference of ComputationIntelligence, Communication System \& Networks, Bali, 2012.

[16]. Hermana and Mien Karmini, Pengembangan Teknologi Pembuatan Tempe, Bunga Rampai Tempe Indonesia, Yayasan Tempe Indonesia, Jakarta, 1996.

[17]. Inohara, H., Training Manual on Japanese Management and Human Resources Development, Asian Productivity Organization, Tokyo, Japan, 1991. 